\title{
The Concept Of Sakinah Family In The Contemporary Muslim Generation
}

\author{
Ahmad Fauzan ${ }^{1}$, Hadi Amroni²
}

\begin{abstract}
Abstrak: The Concept Of Sakinah Family In The Contemporary Muslim Generation. This research tries to reveal the meaning of the Sakinah family as one of the goals of marriage as described in the Al-Qur'an Surah Ar-Rum (30:21). The aim, in addition to gaining a clear understanding of the substantive meaning of the term, is to obtain concepts that can be applied in modern life. In achieving this goal, the researcher tries to examine many opinions of modern interpretive scholars and analyze them using a qualitative descriptive approach. Based on the results of the analysis of several ideas from modern commentators, it can be concluded that the Sakinah family is a family in which harmony, peace, and comfort are created, and runs on legal and religious norms. To realize a sakinah family, every prospective married couple needs to prepare for their marriage from an early age, especially those related to moral, material, mental and spiritual abilities, and have a strong commitment to shaping and maintaining family continuity based on the guidelines and rules of religion and society.
\end{abstract}

Keyword: sakinah family, Qur'anic interpretation; muslim generatioan

Abstrak Konsep Keluarga Sakīnah dalam Generasi Muslim Kontemporer. Penelitian ini mencoba untuk mengungkap makna Keluarga Sakinah sebagai salah satu tujuan pernikahan sebagaimana dijelaskan dalam Alquran Surah Ar-Rum (30:21). Tujuannya, di samping untuk mendapatkan pemahaman yang jelas terhadap makna substantif dari istilah tersebut, adalah untuk memperoleh konsep yang dapat diterapkan dalam kehidupan modern. Dalam mencapai tujuan tersebut, peneliti mencoba menelaah sejumlah pendapat ulama tafsir modern dan menganalisisnya dengan menggunakan pendekatan deskriptif kualitatif. Berdasarkan hasil analisis terhadap sejumlah pemikiran ahli tafsir modern dapat disimpulkan bahwa keluarga sakinah adalah keluarga yang di dalamnya tercipta keharmonisan, kedamaian, dan kenyamanan, serta berjalan di atas norma hukum dan agama. Untuk mewujudkan keluarga sakinah, setiap calon pasangan suami istri perlu mempersiapkan perkawinannya sejak dini, terutama yang berkait dengan kemampuan moril, materil, mental, dan spiritual serta memiliki komitmen yang kuat untuk membentuk dan memelihara. keberlangsungan keluarga berdasarkan pedoman dan aturan agama dan masyarakat.

Kata Kunci: keluarga sakinah, tafsir Alquran; generasi muslim

${ }^{1}$ Faculty of Sharia, State Islamic University of Raden Intan, Lampung, Indonesia

${ }^{2}$ Universiti Utara Malaysia (UUM) Sintok, Kedah, Malaysia

E-mail: ${ }^{1}$ ahmadfauzan@radenintan.ac.id, ${ }^{2}$ serayaku99@gmail.com 


\section{Introduction}

Marriage is an agreement between a man and a woman to live together in a household-based on legal and religious norms. With this bond, each partner will receive mutual rights, obligations, and responsibilities to achieve mutual happiness. Every couple who gets married must yearn for a life of peace, harmony, and prosperity, which is also the main goal in forming a household. For mankind, marriage is something sacred and has a noble purpose, and cannot be separated from the requirements of religious prescriptions.

Apart from encouraging every adult individual to form a household, Islam also emphasizes the importance of decorating a household with worship and adherence to religious teachings. As a Muslim family that is built on legal marriage, Islam needs to be placed as a foundation and guidance in married life. Apart from that, Islam must also be a guide, direction, and way to solve every problem in the household. Families also play a role in children's education so that they become a generation who adhere to the teachings of Islam as a whole (syumū $)$ to achieve the ideals of the world and the happiness of the hereafter. In short, households must always be kept in line with the sakinah family framework. The word sakinah in Islam is used to characterize the institution "family" as a value system that is the driving force in building a happy, comfortable, and prosperous family. Through closeness and servitude to God, household life is expected to run in harmony, peace, and prosperity under the auspices of Allah SWT.

This research is library research using an interpretive approach to examine the conception of the Sakinah family in modern literature so that it can be applied in the life of the contemporary Muslim generation.

\section{The Principles of Marriage}

\section{a. Ability}

The ability or readiness before marriage is a major factor before a marriage takes place. The ability consists of three criteria, such as physical, psychological, and financial abilities. Physical abilities include the readiness of the reproductive organs. This becomes very important because one 
of the functions of marriage is reproduction. Thus, the readiness of the reproductive organs becomes a condition for marriage. The readiness of the reproductive organs is interpreted within the minimum age of marriage, which is 19 years for both potential marriage couples.

Psychical readiness is very closely related to one's maturity. It is regarding what he or she be able to live independently and be able to support his or her family later. Psychical ability is also assessed by the readiness to accept the legal impact of a marriage bond, namely the existence of rights and obligations. Furthermore, this psychological readiness is also related to the knowledge about all matters in domestic life. While financial capability is very urgent in living a domestic life. This financial capability will be the main factor when potential marriage couples are running for domestic life in a family.

\section{b. Comparability (Kafä'ah)}

The meaning of comparability ( $k a f \vec{a} a h)$ is very important for everyone who considers it in a condition of marriage in several ways, which a man (husband candidate) should be the same degree as a woman (wife candidate). ${ }^{1}$ Etymologically, kafäah comes from the Arabic language, which means the same or equivalent. ${ }^{2}$ Kafa'ah or sekufu means equivalent, comparable, balanced, and equal. Sayyid Sabiq stated in his work, Fiqh Sunnah, that in Islamic marriage law, the term kafäah is meant by kufü as known as a man can be equal, equivalent, balanced, or comparable with his wife candidate, equal in position, equal in social level, and equal in character, and wealth. ${ }^{3}$ Kafäah is a term used in fiqh and it usually applies to marriage tradition. The intention of kafäah in marriage is harmony between the husband and wife candidates, so the parties concerned agree to marry. ${ }^{4}$

${ }^{1}$ Muhammad Jawad Mughniyah, Fiqih Lima Mazhab (Jakarta: Lentera, 2007). p. 349.

2 A.W. Munawwir, Kamus Al-Munawwir Arab-Indonesia Terlengkap (Surabaya: Pustaka Progresif, 1997). p. 1221.

${ }^{3}$ Sayyid Sabiq, Fiqh As-Sunnah Jilid II (Beirut: Dâr al-Fikr, 1983). p. 225.

${ }^{4}$ Kamal Mukhtar, Asas-Asas Hukum Islam Tentang Perkawinan (Jakarta: Bulan Bintang, 1974). p. 69. 
In the hadith, as the Messenger of Allah SWT, Rasulullah SAW explained and gave direction in choosing a couple with the following criteria:

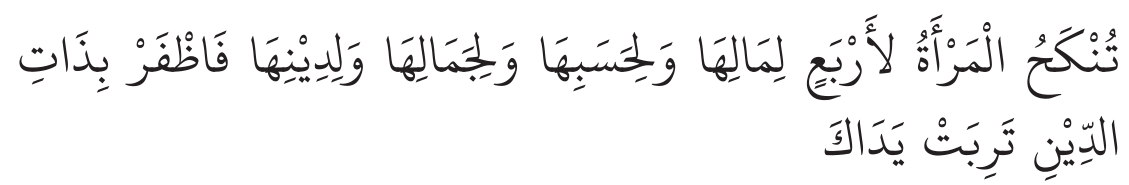

"A woman is married based on four reasons, such as because of her wealth, descendants, beauty, and religion, then choose her because of her religion. It surely makes you lucky"s

Referring to the hadith above, it can be understood that certain criteria contain the philosophical meaning in choosing a couple. Choosing a couple can be done based on four reasons mentioned above, such as because of wealth interest, descent or social condition of the family, a beautiful or handsome physical condition, and good practice of worship is a natural thing. However, at the end of the hadith, there is mentioned that someone who chooses a couple through looking at a good religious background - judged by her or his religious knowledge and practice of worship - would certainly be better off in maintaining the household life later.

A marriage can result in a sakinah family if it is based on love (mawaddah) and affection (rahmah) between the existence of a husband and wife. Thus, a sakinah family is not only demand a husband but also caused by a pious husband. Furthermore, the presence of a virtuous woman in a household life is very needed in realizing these noble ideals. Therefore, this next section will discuss the criteria for righteous husband and wife.

\section{c. Priesthood and Piety}

In this context, religion plays a significant role in forming and maintaining the family until sakinah. Religion is not only important to be learned and preached, but also must be internalized and even

${ }^{5}$ Hadith. Reported by Muslim Number: 3708. 
implemented in daily behavioral life. It must become a spirit and a man is positioned as a body, where all human beings will not live without religion. Religion must be implemented in the social system, starting from the smallest scope of the family to the wider community. Therefore, to goal a sakinah family in marriage, all couples must have a strong commitment to religion as a basis for the problems solving. Commitment here is meant the ability to believe in the existence of Allah SWT as the only One God who has the power and majesty, has responsibility for the teachings of religion in daily life, including recognizing the sacredness of marriage. In other words, the internalization of religion will be a more integrated personality form and play a role in the integrity of marriage.

\section{d. Love (Mawaddah) and Affection (Rahmah)}

Sakinah family cannot be separated from the element of affection (rahmah) among husband, wife, and children. In Islam, affection does not always mean pampering. It can be interpreted as a proportional attitude in placing the rights and obligations. In family institutions, it can be interpreted as an attitude of mutual appreciation for goodness in the form of obedience and doing ishlāh in a good way, if there are mistakes. Completing each other's obligations, giving the rights to each other among family members, and mutual understanding among them is the keyword for ishlahh, especially if something unexpected happened by accentuating the nature of forgiveness.

\section{e. Mutual Relationship (Mu'āsyarah bi al-Ma'rūf)}

Mutual relationship, polite, and wise (mu'āsyarah bi al-ma'rūf) among the family members is a good attitude that must be inherent and become customary in the family life interaction among husband, wife, and children. Besides that, openness must also be manifested in psychiatric interactions, thoughts, attitudes, and behavior. Each can fully recognize the nature of family members' personalities and can foster mutual trust among them, especially between husband and wife. This can be achieved if the husband or wife is open to each other in 
all matters concerning feelings and desires, ideas, and opinions, as well as their nature and personalities. Giving information with the couple avoids prejudice, accuses each other, and keeps away from all behaviors that can cause problems. In this, polite and wise attitude in family interaction are much needed, acted in firmly and not harshly, holding each other's ego with mutual respect. Shortly, wisdom becomes an attitude that must be attached to the husband as a family leader so that he can provide peace in every decision making and the problems solving faced.

\section{f. Knowledge (al-Ilmu)}

Religion is an inseparable part of the fostering of family life. There is no separation of life or dichotomy from the religious values, which is indeed the main guide in life. Therefore, someone who is getting married must build himself as like as his usual family equipment by himself with the adequate understanding of knowledge to form a strong religious foundation in the family. Through a religious foundation, the family building will be sturdy and long-lasting. Religion is a clear spring for everyone who drinks it will eliminate thirst. Therefore, if sakinah family concept is realized in Muslim families, it is expected to realize a prosperous community and environment.

The essence of marriage or sakinah family forming is a natural and also desired by every human being, which the knowledge about the family must be understood by everyone who wants to get married. Like someone who wants to drive a vehicle, he must be good at driving a vehicle and very well know the signs in driving. It is similar to the navigation of the family life. All human beings, especially husband and wife must know the sign, rights, and obligations of the marriage life. Therefore, the understanding of Islamic family law (figh al-munakahat) has to fulfill in practice and not be ignored by all couples. So, it becomes obligatory to be studied in various matters by everyone before getting married. 


\section{g. Deliberation (Openness, Courtesy, and Wisdom)}

Islam guides a married couple to always deliberate in family life. ${ }^{6}$ For further, the realization of the deliberation value can be grouped into four: first, deliberation in deciding the issues related to reproduction, number of children, children's education, and heredity; second, deliberation in deciding the residence place (home); third, deliberation in solving the problems encountered in family life; and fourth, deliberations in the distribution of household tasks. ${ }^{7}$ Besides, in family building, there needs to be open, polite, and wise (mu'āsyarah bi al-márüf). These attitudes must be inherent and become a custom of the interaction within the family life between husband, wife, and children. Moreover, openness must also be manifested in psychiatric interactions, thoughts, attitudes, and behavior. Each of them can fully recognize the personalized nature of the family members and can develop mutual trust among them, especially between husband and wife. This can be achieved if the husband or wife is very open to each other in all matters concerning feelings, desires, ideas, and opinions, as well as nature and personality. Therefore, giving information to each couple, avoid prejudice, accuse each other, and avoid everything that can result in problems. The polite and wise attitudes in interaction, acted firmly without harshly, holding each other's ego with mutual respect to each other can become the wisdom, which is an attitude that must be attached to the husband as a leader in the family, so that it can provide peace in every decision making to solve any problems faced in the family life.

\section{h. Marriage is a Strongly Agreement (Mitsāqān Ghalizhān)}

In the Quran, marriage is called a strong agreement (mitsāqān ghalizhàn), which is stated in the Quran Surah An-Nisa (4) verse 21:

${ }^{6}$ M. Quraish Shihab, Islam Yang Disalahpahami (Ciputat: Lentera Hati, 2018). p. 178. Kaharuddin, Nilai-Nilai Filosofi Perkawinan Menurut Hukum Perkawinan Islam dan Undang-Undang Republik Indonesia Nomor 1 Tahun 1974 Tentang Perkawinan (Jakarta: Mitra Wacana Media). p. 127. 


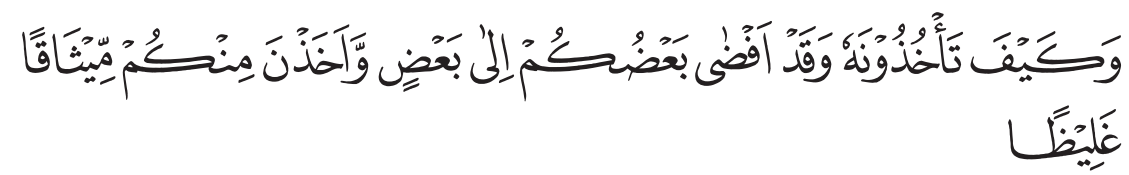

"How you will take it back, even though some of you have mingled (mixed) with others as husband and wife, and they (your wives) have taken from you a strong agreement"

Marriage can be called a strong agreement, because there are so many provisions, conditions, and guidelines set by Islam both in terms of physical, psychological, including material and family relations as well as the relationship of married couples. Marriage is mentioned as mitsāqa ghalizhān because it is bound by love, affection, and trust. So, if the love agreement is broken, there is still an affection, and if the affection is broken, there is still a mandate that can be given by the parents to the children that must be confirmed by the sentence and the name of God. ${ }^{8}$

\section{Sakinah Family}

In the Arabic language, the word sakinah contains the meaning of calm, respectful, safe, loving, steady, and obtaining a defense. So, the sakinah family is a very ideal condition in family life, and the ideal is usually rare. Therefore it does not happen suddenly. It is supported by solid pillars, which require struggle and require time and sacrifice first. ${ }^{9}$ Besides that, the sakinah family is also a mention of maslahah family. Maslahah family is a family whose basic needs can be maintained. These needs include physical and mental needs, including physical-material, and moral-spiritual needs. This understanding is derived from the ideals of the Muslims as maslahah family in which individuals, families, and communities because the problem is the maintenance of basic human needs such as religion, soul, property, descent, and reason. ${ }^{10}$

According to the Decree of the Director-General of Islamic Community Guidance and Hajj Affairs Number: Dj/71/1999 on

${ }^{8}$ M. Quraish Shihab, Islam Yang Saya Pahami (Ciputat: Lentera Hati, 2018). p. 60.

9 Ahmad Mubarok, Psikologi Keluarga (Malang: Madani, 2016). p. 120

${ }^{10}$ Agus Muh. Najib dkk, Membangun Keluarga Sakinah Dan Maslahah (Yogyakarta: PSW \& IISEP-CIDA, 2006). p. 88 
Guidance for the Development of the Sakinah Family Movement Chapter III Article 3 states that a sakinah family is based on legal marriage, capable of fulfilling the spiritual and material needs properly and in balance, filled with an atmosphere of love among family members and their environment in equality, harmony, and being able to be practiced, live, and deepen the values of faith, piety, and noble character. ${ }^{11}$

Islamic scientists have several views regarding the definition of a prosperous family. A Syrian scholar, Wahbah al-Zuhaili, stated that a prosperous family is always iltiza $m^{12}$ guaranteed under the laws prescribed by God and adheres strictly to Islamic morals and manners. The family expert will strive for the goodness in the world and hereafter, strive to live very well in society to achieve world happiness and the glory of the hereafter. ${ }^{13}$ According to him, sakinah will be realized with the support of mawaddah wa rahmah factors. Mawaddah means love, while rahmah means love. Love and affection are the main elements that encourage husband and wife to help each other, uphold the family on a strong foundation and order, and give birth to perfect calm. ${ }^{14}$ Shortly, the term sakinah family is the same as the term happy family or prosperous family.

\section{Sakinah Conception According to the Interpreters}

The sakinah family is a concept whose inspiration comes from the verses of the Qur'an following the position of the Qur'an for people who embrace Islam. ${ }^{15}$ Based on the reason, to explore the meaning of the sakinah family can be obtained through interpretations from experts. There are several interpretations of the sakinah family that are sourced from Q.S. Ar-Rūm (30) verse 21:

${ }^{11}$ Tim Penyusun, Petunjuk Teknis Pembinaan Gerakan Keluarga Sakinah (Jakarta: Kementerian Agama, 2011). p. 21

${ }_{12}$ Strong commitment to religious teachings

${ }^{13}$ Wahbah al-Zuhaili, Al-Ummah Fi al-Quran al-Karim Wa al-Sunnah al-Nabawiyyah (Beirut: Muassasah al-Risalah, 2000).

${ }^{14}$ Wahbah al-Zauhaili, Tafsîr Al-Munîr (Beirut-Libanon: Dâr al-Fikr, 1991). p. 69

${ }^{15}$ Ahmad Mubarok. 


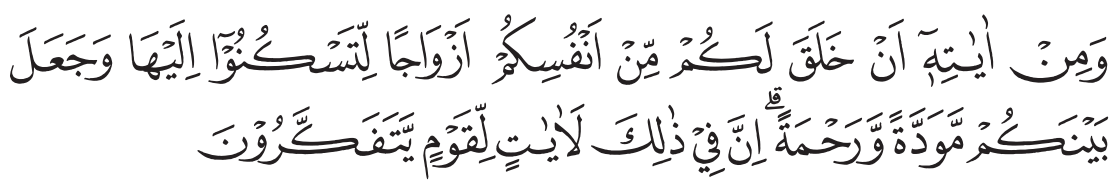

"And among the signs of His power is that He created for you wives of your kind so that you are inclined and feel at ease with him, and He made you with love and affection. Surely in that, there are signs for people who think."

\section{a. Tafsir Al-Azhar by Hamka}

Regarding the Quranic verse above, Hamka commented, "So that you may be at peace with him" which means that life will be restless if you are alone because of loneliness, seclusion is not friends. The man looks for the woman until he can find her and the woman waits for the man to arrive. Life is combined into one, because of it, there are becoming the unity that can directly breed humans because love and affection will naturally grow. The term mawaddatan wa rahmatan can be interpreted with love, which is the longing of a man to a woman and a woman to a man who made God fair from life itself. ${ }^{16}$ Thus, the sakinah family, according to Hamka, is a family that is always together in love and complementing the nature and needs of oneself.

\section{b. Tafsir Al-Mishbah by M. Quraish Shihab}

M. Quraish Shihab defines the sakinah family as a school where our children learn noble qualities. From their mothers, they learn to love, loyalty, and positive jealousy, and so on; and from their father learned courage, tenacity, defense, and so on. ${ }^{17}$ M. Quraish Shihab explained in the Tafsir of Al-Mishbah that the meaning of sakinah is calm after the shock. The shock occurred because someone was not married. Marriage is the only door that allows for sexual intercourse. In this context, Allah SWT creates each creature the urge to unite with his partner let alone each wants to maintain the existence of its kind. He will feel restless, his

${ }^{16}$ Hamka, Tafsir Al-Azhar Juzu' XXI (Jakarta: Pustaka Panjimas, 1986). p. 65

${ }^{17}$ M. Quraish Shihab, Mutiara Hati (Ciputat: Lentera Hati, 2014). p. 66 
mind will be chaotic, and his soul will continue to flare up if the merger and togetherness with this couple have not been fulfilled. Therefore, Allah SWT prescribed for the couple family that the chaos of the mind and the turmoil of the soul subside and also each subject obtains in peace. That is the main purpose of the word li taskun ilaih. ${ }^{18}$

Peace in marriage will not certainly be enough. The next stage to peace in the family is mawaddah, which is forced to need each other in love so that it always wants to give the best to the couple. While the word rahmah, which means affection to the husband and wife will be present with the birth of a child or when a married couple has reached old age. So, when the peace in the household fades, there is still mawaddah. When mawaddah has disappeared, there is still a rahmah. When rahmah is gone, the amanah is the last pillar of marriage as a solid marriage agreement. This is needed in a family, which in essence a person must be one with his couple, which is to unite his body and heart, even his mind. ${ }^{19}$ So, as a whole, the concept of a sakinah family accoding to M. Quraish Shihab's is in accordance with Indonesian marriage law. ${ }^{20}$

\section{c. Thematic Interpretation of the Ministry of Religion: Building a Harmonious Family}

The Quran Surah Ar-Rūm [30] verse 21 informs us that the existence of a person as a couple is aimed to obtain peace. "Peace" in this word is certainly different from the peace experienced by someone when he stays at home after seeking fortune every day. Therefore, peace is the goal of the existence of others as their couple which is spiritual or commonly referred to as tranquility of the soul. It is naturally all men will feel their soul in peace with the presence of a companion at his side, namely his wife. Likewise, women will feel peace with the presence of men as a companion or her husband after their feeling from each experience in shock or anxiety when she is still living alone.

${ }^{18}$ M. Quraish Shihab, Tafsir Al-Mishbah (Ciputat: Lentera Hati, 2012), p. 186.

${ }^{19}$ Ibid, p. 189

${ }^{20}$ Abdul Kholik, "Konsep Keluarga Sakinah dalam Perspektif Quraish Shihab", Inklusif, II.2 (2017). p. 38 
Referring to the explanation above, it can be concluded that the word sakinah with all the finished words shows that the meaning of peace and tranquility, both physical or non-physical and spiritual. Specifically, in the form of sakinah, everything shows the meaning of calmness or peace of mind or soul. This word is not used excepted to describe the serenity and calm after previously experiencing jitters or anxiety, both spiritual and physical in nature. ${ }^{21}$

\section{d. Tafsir Al-Munir by Wahbah Zuhaili}

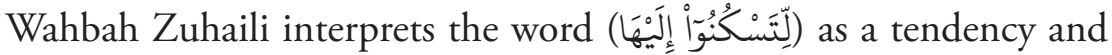
attracted to a couple, feels familiar with him, and does not feel familiar. This is based on the kind of similarity which is a factor in the creation of attraction, harmony, compatibility, and closeness. In the marriage relationship, there will be feelings of love, affection, and compassion. ${ }^{22}$ Thus, the form of a sakinah family in Islam is begun with the selection of the right couple while the main point in choosing a couple is in the same faith and practice of worship.

\section{The Concept of Contemporary sakinah Family}

The concept of contemporary sakinah family in contemporary Quranic interpretation perspective can be described in several points:

\section{a. Faith as a Family Foundation}

Conceptually, the sakinah family in the Qur'an is based on religion through a marriage process. It is a solid sacred agreement based on love, mawaddah, rahmah, and amanah, whose members can be responsible for realizing peace (sakinah) through good association with the division of tasks according to position, status, and function. The family is used as a shelter for its members and the base of the power of society to obtain peace in life. The foundation of family life is religious teachings,

${ }^{21}$ Tim Penyusun, Tafsir Al-Qur'an Tematik: Membangun Keluarga Harmonis (Jakarta: Kementerian Agama, 2008). p. 60

22 Wahbah AZ-Zauhaili, Tafsir Al-Munir Jilid 11 (Jakarta: Gema Insani Press, 2016). p. 97. 
accompanied by physical and mental readiness. Moreover, the glue for family building is based on the rights and obligations sharing following Allah SWT prescribed in the Quran to the husband, wife, and children. ${ }^{23}$

Essentially, to realize the sakinah family is placed in one's piety. Taqwa in the sense of living the commands of Allah and avoiding what is forbidden. If all family members are pious, the family life will refer to the guidelines and rules following the teachings of the Islamic religion. A. M. Ismatulloh added that if a marriage is carried out based on following religious orders and the Sunnah of the Prophet, the sakinah, mawaddah, and rahmah are given by Allah to all human beings, can be enjoyed by a husband and wife. ${ }^{24}$ This is very necessary because Islamic religion consists of the norms and moral values or ethics of life. ${ }^{25}$

According to Imannatul Istiqomah and Mukhlis, there is a relationship between religiosity and marital satisfaction in married couples. It means that if the owned religiosity is higher, the marital satisfaction felt by married couples will also the same higher. Besides, marital satisfaction is also determined by sex, education level, and marriage age. ${ }^{26}$ The family, as the initial institution of earlier religious education for everyone, should instill the values of religious teachings that come from a valid foundation of faith. The purpose of valid here is meant that all religious knowledge in the family must be the knowledge of good and true faith, so it is to build the faith and good character, and it does not base on erroneous religious knowledge that can impact a radical attitude in the faith and results in the disgraceful morals.

After each individual instills faith and piety and produces noble morals, the next is to cultivate a sense of love for others, such as the

${ }^{23}$ Eka Prasetiawati, "Penafsiran Ayat-Ayat Keluarga Sakinah, Mawaddah, Wa Rahmah Dalam Tafsir Al-Misbah Dan Ibnu Katsir”, NIZHAM, Volume 5.2, 2017. p. 142.

${ }^{24}$ A.M. Ismatulloh, "Konsep Sakinah, Mawaddah dan Rahmah dalam Al-Qur'an (Perspektif Penafsiran Kitab Al-Qur'an Dan Tafsirnya)”, Mazahib, XIV (2015), p. 54.

${ }^{25}$ Imam Mustofa, "Keluarga Sakinah dan Tantangan Globalisasi”, Al-Mawarid, XVIII (2008). p. 229

${ }^{26}$ Imannatul Istiqomah, Mukhlis, "Hubungan Antara Religiusitas Dengan Kepuasan Perkawinan”, Jurnal Psikologi, Volume 11.2, 2015, p. 64. 
Allah SWT's love given to His creatures incessantly. This love is not present in the soul in which there is a stain of ignorance, ugliness, and even evil. They are people who do not have social concern for others, indifferent to the present conditions that need help, and egoistic. Based on the reason, in this verse, the Qur'anic verse leads us to ask one another - in the sense of praying to Allah - so we have compassion until humanity will be in line with its proper position.

\section{b. A Beautiful Couple}

The couple's choice is the first thing in building a household and family. Islamic, state, and even customary law have provided direction regarding the selection of the couple. Choose a couple who is sekufu or equal. A matching pair in all aspects - physical, financial, emotional, and knowledge - will be the determinant factors to present a harmonious family relationship. A harmonious and complementary couple in affection, respect, sexual intercourse, and good communication will be the driving force for happiness and peace in the family as well as the goal of marriage in Islam.

\section{c. Based on the Law}

The formation and continuity of the family are based on the guidance and rules that apply and implements the rights and obligations among family members. That is an important point of the meaning of the sakinah family. When a Muslim wants to build a family ladder, he must understand the rule of law relating to building a family with his couple. This is a very important key because the marriage in Islam is part of an event that is regulated in detail, both in religious, state, and even custom law. Through the implementation of the rule of law, someone is ready to develop a family marriage properly and responsibly.

\section{d. The Fulfillment of Standard Needs and the Achievement of Marriage Purpose and Function}

The fulfillment of the standard needs within the family is very important. Standard needs are divided into several aspects such as 
clothing, food, shelter, knowledge, and health, which are carried out together in the family. This togetherness does not certainly eliminate the main responsibility related to family livelihoods that exist on the father or husband. It is also expected to fill the gap so that the fulfillment of family needs can be overcome as much as possible, which in turn can help efforts to realize the goals and functions of marriage.

\section{e. Socialization}

Islam teaches us that the modern Muslim generation must choose a good environment. A good environment is a neighborhood that can provide us a sense of comfort, peace, and safety for our families. It is needed by modern Muslim families to implement religious and social values. It will also impact the modern Muslim family to socialize very well, and the environment has also give a positive impact on the family. Finally, Muslim families can be actively involved and contribute positively to society without breaking the law.

\section{Creating a Sakinah Family among the Modern Muslim Generations}

Islam as a comprehensive religion guided to realize a happy family. All guidelines and guidance have been outlined by the Qur'an, the hadith of the Prophet, and the statements of the Muslim scholars. All problem solutions in the family can be referred to and found. Essentially, Muslims are bound by Sharia ties as the guidelines of certain goals (maquashid al-syarīah) for all Muslims. If there is a significant problem separated from the Sharia norms, it must be returned immediately. If the agreement is released or deliberately removed, there are present various problems in the family. In this case, Islam has provided guidelines to maintain the family. It must be started from the basics of family form, the foundation of Aqeedah and Sharia, understanding the provisions in choosing a couple, character and manners in the family, the rights and obligations in the family, to the management of all problems solving in the family. 


\section{a. Marriage is Begun from Ability}

At the beginning of a marriage, family life still feels beautiful because it is still in an atmosphere of honeymoon and love. ${ }^{27}$ Furthermore, the family must focus on its independence in running family life. According to Siti Romlah, economic and social capabilities, psychological maturity, and religious diversity support a sakinah family form. Besides, religious understanding and religious practices are the most fundamental things. Meanwhile, families may not be convinced because of several factors, such as miscommunication, no ability to fulfill basic needs, and low education, including religious understanding is also very low. ${ }^{28}$

\section{b. Having Insights Regarding on sakinah Family}

The Insights about the sakinah family are essentially explained in the Quran and Al-Hadith. Modern Muslim families are required to explore the meaning of the sakinah family, which must be practiced every day in a life. The insight about the sakinah family can also be related to various other scientific disciplines that are related to family life. Another insight that must have by the parents is parenting. The understanding of parenting must be updated and adapted comprehensively to be following the conditions.

To get pleasure, peace, and safety, there requires some knowledge. To get pleasure, for example, there are needed insights about health, nutrition, economics, management, and other sciences. Likewise, to get peace, there is needed a knowledge of the soul and the intricacies associated with that. Therefore, religious knowledge is required with various aspects listed within. Thus, to build a sakinah family, we need many sciences and not only Islamic law like was happened today. Because to build a sakinah family, there is not enough to see and consider the legal aspects, but also requires much knowledge and approaches. ${ }^{29}$

27 Supriatna, "Mempersiapkan Keluarga Sakinah", Al-Ahwal, 2.1 (2009), p. 22.

${ }^{28}$ Siti Romlah, "Karakteristik Keluarga Sakinah Dalam Perspektif Islam Dan Pendidikan Umum”, Mimbar Pendidikan”, XXV.1 (2006), p. 72.

${ }^{29}$ Khoiruddin Nasution, "Arah Pembangunan Hukum Keluarga Islam Indonesia: Pendekatan Integrative Dan Interkonektif Dalam Membangun Keluarga Sakinah”, Asy-Syir'ah, 46.1 (2012). p. 101 


\section{c. Seriousness and Adaptive}

Ahmad Zaini said that to get happiness in the world and the hereafter, everyone is not only be achieved through devoted to Allah SWT individually but also through the family and society. At the family, the level is needed marriage guidance as a preventive or prevention ways to not occur in the family, which the couple marriage can create happiness in the family. Therefore, the seriousness in family life is certainly related to someone's maturity. It can be related to ready for work and to fulfill the family needs. ${ }^{30}$

\section{d. The Formation and Sustainability of the Family Based on Guidelines and Rules}

Knowledge of rules in family law must be sought as a form of independence. This independence is a form of seriousness in committing to form the sakinah family. If all aspects of life implemented in the formation and continuity of the family based on the application of legal rules, the existence of sakinah family can be maintained and it is ultimately able to achieve the goal of marriage, namely the sakinah family form which is very relevant with the principle of sakinah, mawaddah, and rahmah. Furthermore, if family members become law-abiding individuals, both religious law (worship) and the law imposed by the state, of course, peace, comfort, and security will be present. Moreover, this is done by all modern Muslim families. However, the ideals of civil society in Islam are started from the realization of happy families form.

\section{e. Achieving Family Purpose and Function}

To realize the goals and functions of the sakinah family, it must be done through the commitment to fulfill the rights and obligations of all family members. This seriousness also includes a pattern of good and smooth communication among the family members. This is also

${ }^{30}$ Ahmad Zaini, "Membentuk Keluarga Sakinah Melalui Bimbingan dan Konseling Pernikahan", KONSELING RELIGI, VI.1 (2015), p. 103. See Abdul Qodir Zaelani, "Pola Asuh Anak Dalam Perspektif Yuridis Dan Psikologi Pendidikan", Asas: Jurnal Hukum Ekonomi Syariah 6, no 2 (2014): 29-37. 
based on the reason that marriage is a strong agreement that must be maintained and cared for as well as possible. The division of roles in exercising the rights and obligations can be a solution or innovation in realizing a harmonious family life. This effort must be done voluntarily without making it a burden within the family life. In other words, the comfortable within the sakinah family life will be present among the family members.

\section{Conclusion}

The sakinah family is a happy family form that able to present calmness, comfort, and security following the vision and mission that has been directed from the guidance of religion, regulations and upholds all human values. It can be known through several benchmarks such as: (1) the family members have good faith and its implementation both in knowledge or pious; (2) a harmonious and complementary married couple is feeling in love, respect, the conduct of good sex, and communication between one to each other; (3) the formation and continuity of the sakinah family are based on guidelines and the implementation of rules, and the fulfillment of the rights and obligations among each family member; (4) the fulfillment of standard needs (clothing, food, shelter, knowledge, and health) and the achievement of the objectives and functions of marriage; (5) actively involved and contributing positively to the community without breaking up the law. Furthermore, to realize the sakinah family among the modern Muslim generation or in the contemporary period, there are needed several aspects, such as: (1) the marriage is started from the abilities which consist of physical, psychological, financial and knowledge abilities; (2) having insight about sakinah, mawaddah, and rahmah families as well as comprehensive parenting methods that are continually updated and adapted following contemporary conditions; (3) the seriousness in the sakinah family life is always adapting the various conditions; (4) the formation and continuity of the sakinah family are based on the guidance and rules; and (5) achieving family purpose and function. 


\section{Biblioghraphy}

Abdul Kholik, 'Konsep Keluarga Sakinah dalam Perspektif Quraish Shihab', Inklusif, II.2 (2017).

A.M. Ismatulloh, 'Konsep Sakinah, Mawaddah dan Rahmah dalam al-Qur'an (Prespektif Penafsiran Kitab Al-Qur'an dan Tafsirnya)', Mazahib, XIV (2015), 54.

A.W. Munawwir, Kamus Al-Munawwir Arab-Indonesia Terlengkap. Surabaya: Pustaka Progresif, 1997.

Asnawi, Muhammad. Nikah dalam Perbincangan dan Perbedaan. Yogyakarta: Darussalam, 2004.

Asmaya, Enung. 'Implementasi Agama dalam Mewujudkan Keluarga Sakinah', Jurnal Dakwah \& Komunikasi, 6.1 (2012) <https://doi. org/10.24090/komunika.v6i1.341>.

Chadijah, Siti. 'Karakteristik Keluarga Sakinah dalam Islam', Rausyan Fikr, 14 (2018), 113-28.

D. C. Shin \& D. M. Johnson, 'Avowed Happiness as an Overall Assessment of the Quality of Life', Social Indicators Research, 5.1-4 (2017), 475-492.

Hamka, Tafsir Al-Azhar Juzu’ XXI. Jakarta: Pustaka Panjimas, 1986.

Istiqomah, Imannatul, Mukhlis, 'Hubungan antara Religiusitas dengan Kepuasan Perkawinan', Jurnal Psikologi, 11.2.

Kaharuddin, Nilai-Nilai Filosofi Perkawinan Menurut Hukum Perkawinan Islam dan Undang-Undang Republik Indonesia Nomor 1 Tahun 1974 Tentang Perkawinan. Jakarta: Mitra Wacana Media, t.t.

Kamal Mukhtar, Asas-asas Hukum Islam tentang Perkawinan. Jakarta: Bulan Bintang, 1974.

Mubarok, Ahmad. Psikologi Keluarga. Malang: Madani, 2016.

Mughniyah, Muhammad Jawad Fiqih Lima Mazhab. Jakarta: Lentera, 2007. Mustofa, Imam. 'Keluarga Sakinah dan Tantangan Globalisasi', Al-Mawarid, XVIII (2008), 229.

Najib, Agus Muh. dkk, Membangun Keluarga Sakinah dan Maslahah. Yogyakarta: PSW \& IISEP-CIDA, 2006. 
Nasution, Khoiruddin. 'Arah Pembangunan Hukum Keluarga Islam Indonesia: Pendekatan Integratif dan Interkonektif dalam Membangun Keluarga Sakinah', Asy-Syir'ah, 46.1 (2012).

—, 'Membangun Keluarga Bahagia (SMART)', Jurnal Al-Ahwal, 1 (2009).

Petunjuk Teknis Pembinaan Gerakan Keluarga Sakinah. Jakarta: Kementerian Agama, 2011.

Prasetiawati, Eka. 'Penafsiran Ayat-Ayat Keluarga Sakinah, Mawaddah, Wa Rahmah Dalam Tafsir Al-Misbah Dan Ibnu Katsir', NIZHAM, V.002 (2017).

Romlah, Siti. 'Karakteristik Keluarga Sakinah dalam Perspektif Islam dan Pendidikan Umum', Mimbar Pendidikan, XXV.1 (2006), 72.

Sabiq, Sayyid. Figh As-Sunnah Jilid II. Beirut: Dâr al-Fikr, 1983.

Shihab, M. Quraish. Islam Yang Disalahpahami. Ciputat: Lentera Hati, 2018.

_-, Islam Yang Saya Pahami. Ciputat: Lentera Hati, 2018.

—, Mutiara Hati. Ciputat: Lentera Hati, 2014.

—, Tafsir Al-Mishbah. Ciputat: Lentera Hati, 2012.

Supriatna, 'Mempersiapkan Keluarga Sakinah', Al-Ahwal, 2.1 (2009), 22. Tim Penyusun, Tafsir Al-Qur'an Tematik: Membangun Keluarga Harmonis. Jakarta: Kementerian Agama, 2008.

Zuhaili, Wahbah al-. Tafsîr Al-Munîr. Beirut-Libanon: Dâr al-Fikr, 1991. —, Al-Umumah Fi al-Quran al-Karim Wa al-Sunnah al-Nabawiyyah. Beirut: Muassasah al-Risalah, 2000.

—, Tafsir Al-Munir. Jakarta: Gema Insani Press, 2016.

Zaini, Ahmad. 'MeMbentuk Keluarga Sakinah Melalui Bimbingan dan Konseling Pernikahan', Konseling Religi, VI.1 (2015), 104.

Zaelani, Abdul Qodir. "Pola Asuh Anak Dalam Perspektif Yuridis Dan Psikologi Pendidikan”, Asas: Jurnal Hukum Ekonomi Syariah 6, no 2 (2014). 